Journal of Education and Teaching Learning (JETL) 2019

Vol. 1, No. 3, 1-8

Journal Homepage: http://pusdikra-publishing.com/index.php/jet1

\title{
MENINGKATKAN KEMAMPUAN MENYELESAIKAN MASALAH PENDIDIKAN JASMANI DAN OLAHRAGA (PJOK) SISWA MELALUI PEMBELAJARAN BERBASIS MASALAH DI KELAS V-A SDN.105855 PTP II TANJUNG MORAWA KECAMATAN TANJUNG MORAWA KABUPATEN DELI SERDANG
}

\author{
Anwar Prayitno*)
}

\begin{abstract}
Abstrak
Penelitian ini bertujuan untuk meningkatkan kemampuan menyelesaikan masalah Pendidikan Jasmani dan Olahraga (PJOK) siswa terhadap pembelajaran melalui pelaksanaan pembelajaran berbasis masalah. Penelitian ini merupakan penelitian tindakan kelas yang dilakukan di kelas V-A SD Negeri 105855 PTP II Tanjung Morawa Kecamatan Tanjung Morawa Kabupaten Deli Serdang dengan jumlah siswa 29 orang. Instrumen yang digunakan untuk mengumpulkan data terdiri dari tes kemampuan menyelesaikan masalah, lembar observasi aktivitas siswa dan kemampuan guru dalam mengelola pembelajaran.Hasil penelitian menunjukkan : pembelajaran berbasis masalah dapat meningkatkan kemampuan menyelesaikan masalah Pendidikan Jasmani dan Olahraga siswa,dari 19 orang pada siklus I menjadi 24 Orang pada siklus II, untuk rata-rata kelas dan $67,85 \%$ pada siklus I menjadi $89,14 \%$ pada siklus II untuk ketuntasan kelas. Bagi para guru agar menerapkan pembelajaran berbasis masalah sebagai salah satu alternatif upaya meningkatkan kualitas proses dan hasil pembelajaran Pendidikan Jasmani dan Olahraga siswa.
\end{abstract}

Kata kunci : Menyelesaikan Masalah PJOK, Pembelajaran Berbasis Masalah

\section{PENDAHULUAN}

Depdiknas (2006), pendekatan pemecahan masalah merupakan salah satu fokus dalam pembelajaran Pendidikan Jasmani dan Olahraga untuk mengembangkan kemampuan siswa. Untuk meningkatkan kemampuan memecahkan masalah perlu dikembangkan keterampilan memahami masalah, membuat model Pendidikan Jasmani dan Olahraga, menyelesaikan masalah, dan menafsirkan solusinya.Oleh karena itu dalam setiap kesempatan pembelajaran Pendidikan Jasmani dan Olahraga hendaknya dimulai dengan pengenalan masalah yang sesuai dengan situasi (Contextual Problem).

Dengan pemberian masalah kontekstual siswa secara bertahap dibimbing untuk menguasai konsep.Trianto (2007) menyatakan dalam kenyataannya kualitas pembelajaran Pendidikan Jasmani dan Olahraga di sekolah dasar masih belum memuaskan. Berdasarkan temuan dari Depdiknas, siswa hanya menghafal konsep yang diajarkan guru dan kurang mampu menggunakan konsep tersebut jika menemui masalah dalam kehidupan nyata, serta siswa kurang mampu menentukan masalah dan menemukan solusi pemecahanan masalah.

\footnotetext{
*) Penulis adalah guru SDN.105855 PTP II Tanjung Morawa Kec. Tanjung Morawa Kabupaten Deli Serdang
} 
MENINGKATKAN KEMAMPUAN MENYELESAIKAN MASALAH PENDIDIKAN JASMANI DAN OLAHRAGA (PJOK) SISWA MELALUI PEMBELAJARAN BERBASIS MASALAH DI KELAS V-A SDN.105855 PTP II TANJUNG MORAWA KECAMATAN TANJUNG MORAWA KABUPATEN DELI SERDANG

Kesulitan siswa dalam menyelesaikan masalah-masalah Pendidikan Jasmani dan Olahraga juga terjadi di SD Negeri 105855 PTP || Tanjung Morawa Kecamatan Tanjung Morawa Kabupaten Deli Serdang khususnya di kelas V-A. Berdasarkan pengalaman dan catatan perkembangan prestasi belajar siswa yang dilakukan peneliti selama mengajar Pendidikan Jasmani dan Olahraga di kelas V-A, menunjukkan bahwa kemampuan siswa dalam menyelesaikan masalah Pendidikan Jasmani dan Olahraga masih rendah. Rendahnya kemampuan siswa dalam menyelesaikan masalah yang berkaitan dengan Hidup Sehat.

Berdasarkan jawaban,siswa tidak dapat memahami apa yang menjadi masalah pada soal tersebut.Siswa tidak dapat menentukan solusi yang tepat untuk menjawab permasalahan,sehingga penyelesaian akhir yang diberikan adalah salah.Sehingga dapat disimpulkan bahwa siswa belum mampu menyelesaikan masalah PJOK dengan benar.

Berdasarkan hasil tes menunjukkan bahwa kemampuan siswa dalam menyelesaikan masalah PJOK masih rendah.Perolehan nilai rata-rata kelas Pra siklus untuk materi menyelesaikan masalah yang berkaitan dengan Hidup Sehat hanya mencapai 59,82 di bawah nilai rata-rata kelas yang diharapkan yaitu 70,00 . Jumlah siswa yang tuntas adalah $42,85 \%$, masih di bawah target yang ditetapkan sebesar $80 \%$.

Kondisi pembelajaran yang selalu didominasi oleh guru (Teacher Centered) menyebabkan siswa tidak terlibat secara aktif dalam setiap kegiatan pembelajaran. Hal ini, terlihat dalam setiap proses pembelajaran siswa kurang berpartisipasi dalam menggali atau memperoleh pengetahuan seperti: jarang mengajukan pertanyaan, jarang mengeluarkan pendapat atau tanggapan, jarang menyampaikan kritikan padahal tahu sesuatu itu salah, misal guru dalam menyampaikan sesuatu salah tetapi siswa hanya diam saja dan menerima hal yang salah tersebut.Siswa tidak berusaha untuk menyampaikan apa yang dia telah ketahui sebelumnya dikarenakan takut salah atau malu kepada teman atau guru.

Untuk mengatasi permasalahan di atas diperlukan sebuah strategi dalam mengajarkan PJOK yang dapat mendorong dan merangsang siswa untuk lebih aktif dan kreatif dalam proses pembelajaran, lebih berinteraksi dalam pembelajaran. Siswa diajak untuk berpikir bagaimana memecahkan suatu masalah.Dalam pembelajaran siswa harus berperan aktif membentuk pengetahuan bukan hanya menerima secara pasif dari guru, siswa perlu diberi tantangan dan bantuan yang sesuai dari guru dan teman sebaya yang lebih mampu sehingga dapat bergerak memperoleh pengetahuan baru, dan siswa harus dipandang sebagai subjek yang memiliki potensi untuk dikembangkan sesuai dengan penalarannya sehingga dapat menemukan sendiri konsep-konsep sebagai dasar pengetahuan dengan benar.Kondisi pembelajaran seperti ini sesuai dengan ciri-ciri 
MENINGKATKAN KEMAMPUAN MENYELESAIKAN MASALAH PENDIDIKAN JASMANI DAN OLAHRAGA (PJOK)

SISWA MELALUI PEMBELAJARAN BERBASIS MASALAH DI KELAS V-A SDN.105855 PTP II TANJUNG MORAWA KECAMATAN TANJUNG MORAWA KABUPATEN DELI SERDANG

pembelajaran berbasis masalah yang tidak hanya sekedar mempelajari pengetahuan tetapi membuat siswa belajar mandiri.

Amir (2010) mengatakan pembelajaran berbasis masalah banyak diadopsi untuk menunjang pendekatan pembelajaran Learner Centered.Karena ciri-cirinya yang menjadikan pembelajaran dimulai dengan pemberian masalah yang kontekstual, siswa secara kelompok aktif merumuskan masalah, mengidentifikasi kesenjangan pengetahuan mereka, mempelajari dan mencari sendiri materi yang terkait dengan masalah, dan melaporkan solusi dari masalah. Dengan demikian, siswa akan membekali dirinya di masa datang dan dapat belajar sepanjang hidupnya tanpa harus ada orang lain. Salah satu metode pembelajaran yang diprediksi dapat meningkatkan hasil belajar dan meningkatkan kemampuan berpikir kritis siswa adalah melalui pembelajaran berbasis masalah.

Pembelajaran berbasis masalah merupakan pembelajaran yang bertujuan merangsang terjadinya proses berpikir tingkat tinggi dalam situasi yang berorientasi masalah.Pembelajaran berbasis masalah dirancang membantu siswa untuk mengembangkan keterampilan berpikir dan mengatasi masalah dengan mengalaminya melalui berbagai situasi riil.Kolaborasi siswa dalam pembelajaran mendorong penyelidikan dan dialog bersama dalam pengembangan keterampilan berpikir dan keterampilan sosial (Arends, 2008).

Berdasarkan uraian di atas,maka peneliti akan mengkaji masalah ini melalui Penelitian Tindakan Kelas dengan menerapkan pembelajaran yang lebih inovatif untuk meningkatkan kemampuan menyelesaikan masalah PJOK siswa melalui Pembelajaran Berbasis Masalah di kelas VA SD Negeri 105855 PTP II Tanjung Morawa Kecamatan Tanjung Morawa Kabupaten Deli Serdang.

\section{Kemampuan Menyelesaikan Masalah PJOK}

Berdasarkan pendapat beberapa ahli, suatu pertanyaan merupakan masalah PJOK jika: (1) pertanyaan tersebut tidak dapat dijawab secara langsung dengan menggunakan prosedur rutin tetapi masih harus menyelesaikannya melalui seleksi data informasi dan organisasi konsep yang dimilikinya, (2) pertanyaan harus dapat dimengerti artinya suatu pertanyaan pada bidang tertentu akan merupakan masalah hanya bagi mereka yang mempelajari atau berkecimpung di dalamnya, (3) pertanyaan merupakan tantangan untuk dijawab yang sifatnya individu dan bergantung pada waktu, dan (4) pertanyaan bersifat relatif tergantung situasi dan kondisi seseorang yang menghadapinya.

Penyelesaian masalah diartikan sebagai penggunaan PJOK baik untuk PJOK itu sendiri maupun aplikasi PJOK dalam kehidupan sehari-hari dan ilmu pengetahuan yang lain secara kreatif untuk menyelesaikan masalah-masalah yang belum kita ketahui penyelesaiannya atau pun masalahmasalah yang belum kita kenal. Pemecahan atau penyelesaian masalah merupakan proses penerimaan tantangan dan kerja keras untuk menyelesaikan masalah tersebut. Penyelesaian tidak 
MENINGKATKAN KEMAMPUAN MENYELESAIKAN MASALAH PENDIDIKAN JASMANI DAN OLAHRAGA (PJOK)

SISWA MELALUI PEMBELAJARAN BERBASIS MASALAH DI KELAS V-A SDN.105855 PTP ॥I TANJUNG MORAWA KECAMATAN TANJUNG MORAWA KABUPATEN DELI SERDANG

menggunakan prosedur rutin tetapi menggunakan berpikir keras untuk mendapatkan cara menyelesaikan suatu masalah (Hudoyo dan Sutawijaya (1997:189).

Dengan demikian, kemampuan menyelesaikan masalah PJOK adalah kesanggupan yang dimiliki siswa menggunakan PJOK untuk menyelesaikan masalah sehari-hari atau masalah-masalah yang memiliki konteks dengan dunia nyata dengan menggunakan langkah-langkah atau prosedur menyelesaikan masalah. Prosedur atau langkah-langkah menyelesaikan masalah yang digunakan dalam penelitian ini adalah empat langkah yang dikemukakan Polya yaitu: (1) pemahaman terhadap permasalahan, (2) perencanaan penyelesaian masalah, (3) melaksanakan perencanaan penyelesaian masalah, dan (4) melihat kembali penyelesaian. Karena penelitian ini dilaksanakan di Sekolah Dasar, maka langkah Pola yang digunakan adalah dibuat sesederhana mungkin.

\section{Pembelajaran Berbasis Masalah (PBL)}

Arends (2008:41) menyatakan PBL adalah pembelajaran yang memberikan peran kepada guru sebagai yang menyodorkan berbagai masalah, memberikan pertanyaan, dan memfasilitasi investigasi dan dialog.Selain itu, guru menyediakan scaffolding.Scaffolding adalah suatu proses untuk membantu siswa menuntaskan masalah tertentu melampui kapasitas perkembanganya melalui bantuan guru, teman atau orang lain yang memiliki kemampuan lebih. Dengan menyuguhkan berbagai situasi bermasalah yang autentik dan bermakna kepada siswa, dapat berfungsi sebagai batu loncatan untuk investigasi dan penyelidikan.Dengan demikian, PBM merupakan suatu pendekatan pembelajaran dimana siswa mengerjakan permasalahan yang autentik dengan maksud untuk menyusun pengetahuan mereka sendiri, mengembangkan inkuiri, dan keterampilan berpikir tingkat lebih tinggi, mengembangkan kemandirian, dan percaya diri.

Arends (2008:57) mengemukakan terdapat lima fase atau langkah pembelajaran berbasis masalah tentang perilaku guru dan siswa. Kelima fase atau langkah tersebut tentang langkah PBM disajikan pada tabel 1 berikut ini.

Tabel 1.Langkah-langkah Pembelajaran Berbasis Masalah

\begin{tabular}{|c|l|l|}
\hline Fase & \multicolumn{1}{|c|}{ Indikator } & \multicolumn{1}{c|}{ Tingkah Laku Guru } \\
\hline 1 & $\begin{array}{l}\text { Orientasi siswa pada } \\
\text { masalah }\end{array}$ & $\begin{array}{l}\text { Guru menjelaskan tujuan pembelajaran, menjelaskan } \\
\text { logistik yang dibutuhkan, dan memotivasi siswa untuk } \\
\text { terlibat dalam penyelesaian masalah yang dipilih. }\end{array}$ \\
\hline 2 & $\begin{array}{l}\text { Mengorganisasi siswa } \\
\text { untuk belajar }\end{array}$ & $\begin{array}{l}\text { Guru membantu siswa mendefinisikan dan } \\
\text { mengorganisasikan tugas-tugas belajar yang berhubungan } \\
\text { dengan masalah }\end{array}$ \\
\hline 3 & $\begin{array}{l}\text { Membimbing } \\
\text { penyelidikan individual } \\
\text { maupun kelompok }\end{array}$ & $\begin{array}{l}\text { Guru mendorong siswa untuk mengumpulkan informasi } \\
\text { yang tepat, melaksanakan eksperimen, melaksanakan } \\
\text { observasi untuk mendapat penjelasan dan menyelesaikan } \\
\text { masalah }\end{array}$ \\
\hline 4 & Mengembangkan dan & Guru membantu siswa dalam merencanakan dan \\
\hline
\end{tabular}




\begin{tabular}{|c|l|l|}
\hline & menyajikan hasil karya & $\begin{array}{l}\text { menyiapkan karya yang sesuai seperti laporan, dan } \\
\text { membantu mereka untuk berbagi tugas. }\end{array}$ \\
\hline 5 & $\begin{array}{l}\text { Menganalisis dan } \\
\text { mengevaluasi proses } \\
\text { penyelesaian masalah }\end{array}$ & $\begin{array}{l}\text { Guru membantu siswa untuk melakukan refleksi atau } \\
\text { evaluasi terhadap penyelidikan mereka dan proses-proses } \\
\text { yang mereka gunakan. }\end{array}$ \\
\hline
\end{tabular}

\section{METODE PENELITIAN}

\section{Jenis dan Subjek Penelitian}

Jenis penelitian ini adalah penelitian tindakan kelas (Classroom Action Research) yang bertujuan meningkatkan kemampuan menyelesaikan masalah PJOK melalui Pembelajaran Berbasis Masalah pada siswa Kelas V-A SD Negeri 105855 PTP II Tanjung Morawa Kecamatan Tanjung Morawa Kabupaten Deli Serdang dengan jumlah 28 orang siswa.

\section{Rancangan dan Instrumen Penelitian}

Rancangan penelitian tindakan ini menggunakan siklus PTK yang dikemukakan Arikunto, terdiri dari empat tahapan penelitian tindakan, yaitu (1) perencanaan, (2) pelaksanaan, (3) pengamatan, dan (4) refleksi. Penelitian ini dilaksanakan dalam dua siklus dengan tahapan siklus PTK seperti terlihat pada gambar 2 berikut.

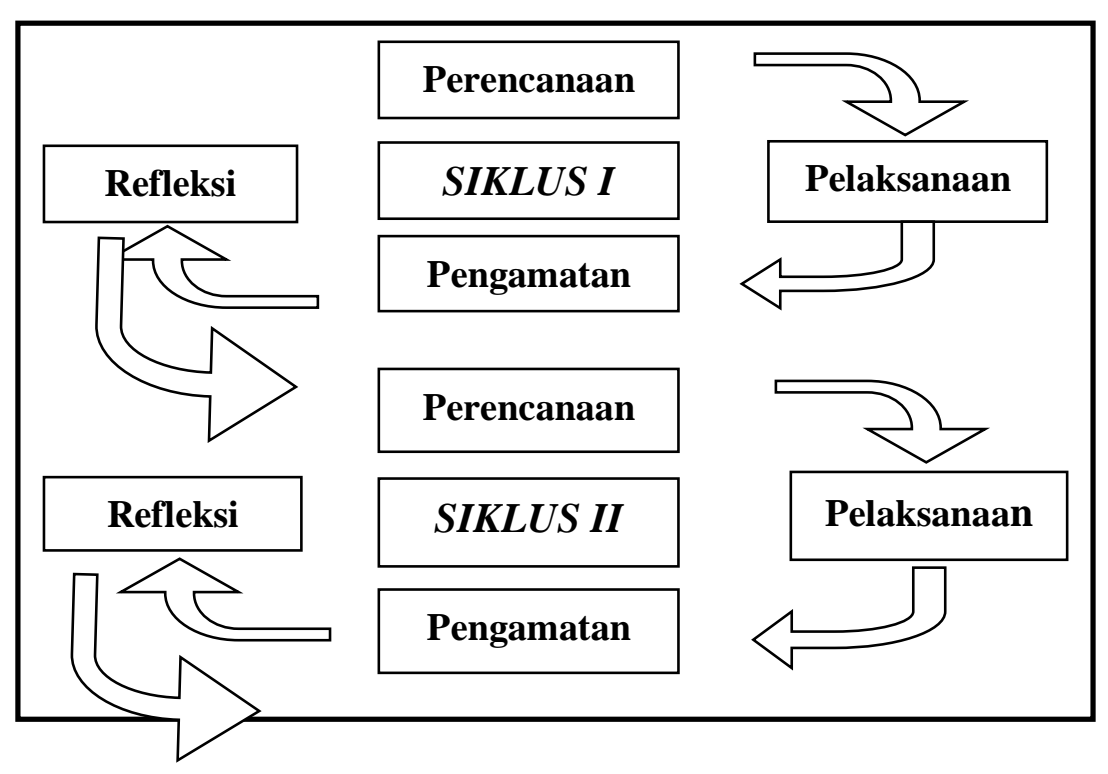

\section{Gambar 2 Siklus PTK Arikunto}

Instrument penelitian menggunakan tes kemampuan menyelesaikan masalah PJOK.Jumlah soal tes yang diberikan sebanyak lima soal berbentuk uraian. Soal tes kemampuan menyelesaikan masalah diberikan pada setiap akhir siklus. 
MENINGKATKAN KEMAMPUAN MENYELESAIKAN MASALAH PENDIDIKAN JASMANI DAN OLAHRAGA (PJOK)

SISWA MELALUI PEMBELAJARAN BERBASIS MASALAH DI KELAS V-A SDN.105855 PTP II TANJUNG MORAWA

\section{HASIL PENELITIAN DAN PEMBAHASAN} KECAMATAN TANJUNG MORAWA KABUPATEN DELI SERDANG

Pelaksanaan tindakan setiap pertemuan mengacu pada RPP yang telah disusun, meliputi: (1) kegiatan awal yaitu mempersiapkan siswa untuk belajar dan menyampaikan appersepsi tentang pembelajaran sebelumnya, (2) kegiatan inti yaitu orientasi siswa terhadap masalah, mengorganisasikan siswa untuk belajar, membimbing penyelidikan, mengembangkan dan presentasi hasil diskusi, analisis dan evaluasi proses penyelesaian masalah, dan (3) kegiatan akhir yaitu: memberi penghargaan, tugas mandiri (PR) dan menyampaikan materi selanjutnya.

Pelaksanaan tindakan pada kegiatan inti diawali dengan melakukan orientasi siswa kepada masalah meliputi menyampaikan tujuan pembelajaran, menyampaikan proses pembelajaran melalui PBM, memotivasi siswa untuk terlibat dalam pembelajaran dengan menyampaikan masalah kontekstual melalui tanya-jawab, dan meminta siswa untuk menjelaskan kembali masalah.

Setelah orientasi siswa terhadap masalah, guru meminta siswa untuk duduk menurut kelompoknya, kemudian membagikan LKS kepada setiap kelompok dan menjelaskan cara kerja dalam kelompok agar diskusi berjalan lancar dan efektif. Diskusi kelompok diawali dengan pembagian tugas pada setiap anggota kelompok.Selanjutnya siswa berdiskusi melakukan penyelidikan untuk memahami dan menemukan solusi penyelesaian masalah.Jika sebagian besar kelompok mengalami kendala dalam diskusinya, guru menghentikan sementara untuk memberikan Scaffolding.Setelah diskusi selesai,siswa menyusun laporan hasil diskusi pada LKS. Kemudian guru memilih 2 atau 3 kelompok untuk menyajikan hasil diskusi, dilanjutkan dengan melakukan refleksi terhadap proses penyelesaian masalah.

Untuk memperoleh data hasil penelitian dilakukan (1) pengamatan terhadap aktivitas siswa selama pembelajaran dan kemampuan guru dalam mengelola pembelajaran menggunakan lembar observasi keaktivan siswa dan lembar observasi kemampuan guru oleh dua orang pengamat, dan (2) dilakukan tes kemampuan menyelesaikan masalah PJOK pada setiap akhir siklus masing-masing lima soal uraian.

Pemaparan hasil penelitian tentang kemampuan menyelesaikan masalah PJOK terhadap pembelajaran berbasis masalah disajikan sebagai berikut.Adapun rangkuman hasil analisis tes kemampuan menyelesaikan masalah PJOK siswa dari siklus I sampai dengan siklus II disajikan pada tabel 2.

Tabel 2.Kemampuan Menyelesaikan Masalah PJOK Siklus I

\begin{tabular}{|c|l|c|c|c|}
\hline No & \multicolumn{1}{|c|}{$\begin{array}{c}\text { Kemampuan Menyelesaikan } \\
\text { Masalah }\end{array}$} & \multicolumn{3}{|c|}{ Persentase Kemampuan } \\
\cline { 3 - 5 } & \multicolumn{1}{|c|}{$\begin{array}{c}\text { Siklus 1 } \\
\text { Siklus 2 }\end{array}$} & Kategori \\
\hline 1 & Memahami masalah & $71,83 \%$ & $98,00 \%$ & Sangat Tinggi \\
\hline 2 & Merencanakan penyelesaian masalah & $80,52 \%$ & $97,00 \%$ & Sangat Tinggi \\
\hline 3 & Melaksanakan rencana penyelesaian masalah & $68,74 \%$ & $86,33 \%$ & Sangat Tinggi \\
\hline
\end{tabular}


MENINGKATKAN KEMAMPUAN MENYELESAIKAN MASALAH PENDIDIKAN JASMANI DAN OLAHRAGA (PJOK) SISWA MELALUI PEMBELAJARAN BERBASIS MASALAH DI KELAS V-A SDN.105855 PTP II TANJUNG MORAWA KECAMATAN TANJUNG MORAWA KABUPATEN DELI SERDANG

\begin{tabular}{|c|l|c|c|c|}
\hline 4 & Memeriksa kembali penyelesaian masalah & $48,51 \%$ & $68,21 \%$ & Sangat rendah \\
\hline \multicolumn{2}{|c|}{ Rata-rata } & $\mathbf{6 7 , 8 5 \%}$ & $\mathbf{8 9 , 1 4 \%}$ & Tinggi \\
\hline
\end{tabular}

Berdasarkan tabel 2 dapat dilihat persentase kemampuan aspek (1), (2), dan (3) menunjukkan kriteria keberhasilan dengan kategori sangat tinggi. Pada aspek pemeriksaan kembali terhadap penyelesaian masalah menunjukkan kategori sangat rendah.Secara umum persentase kemampuan menyelesaikan masalah pada siklus II lebih baik dari siklus I dengan persentase klasikal mencapai $89,14 \%$.

Sedangkan perolehan nilai hasil tes kemampuan menyelesaikan masalah tentang nilai tertinggi, nilai terendah, rata-rata kelas, dan ketuntasan kelas siklus I sampai II seperti yang tertera pada tabel 3 berikut.

Tabel 3. Perolehan Ketuntasan dan Rata-Rata Kelas

Kemampuan Siswa Menyelesaikan Masalah PJOK

\begin{tabular}{|l|c|c|}
\hline \multicolumn{1}{|c|}{ Aspek Analisis } & Siklus I & Siklus II \\
\hline Jumlah Siswa yang Tuntas & 19 orang & 24 orang \\
\hline Persentase Ketuntasan & $67,85 \%$ & $85,71 \%$ \\
\hline Rata-rata Kelas & 67,85 & 89,14 \\
\hline Ketuntasan Kelas & Tidak Tuntas & Tuntas \\
\hline
\end{tabular}

Berdasarkan tabel 3 di atas, dapat dilihat bahwa kemampuan siswa menyelesaikan masalah PJOK pada siklus II adalah tuntas. Berdasarkan indikator keberhasilan, dapat disimpulkan bahwa kemampuan siswa menyelesaikan masalah PJOK melalui Pembelajaran Berbasis Masalah mengalami peningkatan.

\section{KESIMPULAN}

Berdasarkan hasil pengolahan data penelitian, maka dapat disimpulkan bahwa Pembelajaran berbasis masalah dapat meningkatkan kemampuan menyelesaikan masalah PJOK siswa kelas V-A SD Negeri 105855 PTP II Tanjung Morawa Kecamatan Tanjung Morawa Kabupaten Deli Serdang pada Materi Hidup Sehat.Rata-rata kelas untuk kemampuan menyelesaikan masalah PJOK mengalami peningkatan dari 67,85 pada siklus I menjadi 89,14 pada siklus II. Sedangkan ketuntasan kelas mengalami peningkatan dari $68 \%$ pada siklus I menjadi $89 \%$ pada siklus II.

\section{DAFTAR PUSTAKA}

Amir, M. Taufiq, 2010.Inovasi Pendidikan melalui Problem Based Learning. Jakarta: Prenada Media Group. 
MENINGKATKAN KEMAMPUAN MENYELESAIKAN MASALAH PENDIDIKAN JASMANI DAN OLAHRAGA (PJOK) SISWA MELALUI PEMBELAJARAN BERBASIS MASALAH DI KELAS V-A SDN.105855 PTP II TANJUNG MORAWA KECAMATAN TANJUNG MORAWA KABUPATEN DELI SERDANG

Arends, R.I. 2008. Learning To Teach: Belajar untuk Mengajar. Yogyakarta: Pustaka Pelajar.

Arikunto, dkk. 2009. Penelitian Tindakan Kelas. Jakarta: Bumi Aksara.

Fadhli, M. (2019a). Pengembangan Perguruan Tinggi Di Era Revolusi Industri 4.0. In TRANSFORMASI KEBIJAKAN PENDIDIKAN TINGGI ISLAM: Arah Baru Perubahan Kebijakan Pendidikan Tinggi Islam (pp. 269-292). Kalimedia.

Trianto, 2009.Mendesain Model Pembelajaran Inovatif-Progresif: Konsep, Landasan, dan Implementasinya Pada Kurikulum Tingkat Satuan Pendidikan (KTSP). Jakarta: Prenada Media Group.

Zaini, M. F. (2019). The Implementation Of Learning Management In Class VIII Madrasa Tsanawiyah Islamiyah (Mts) Ypi Batangkuis. International Conference on Islamic Educational Management (ICIEM). 